EESTI NSV TEADUSTE AKADEEMIA TOIMETISED. XVIII KÖIDE KEEMIA * GEOLOOGIA, 1969, Nr. 2

ИЗВЕСТИЯ АКАДЕМИИ НАУК ЭСТОНСКОЙ ССР. ТОМ ХVIII ХИМИЯ * ГЕОЛОГИЯ, 1969, 스 2

К. ОРВНКУ, К. ОРВНКУ мл.

\title{
ЗАВИСИМОСТЬ МОРФОЛОГИЧЕСКОГО СТРОЕНИЯ АБРАЗИОННЫХ БЕРЕГОВ ПОДНИМАЮЩЕГОСЯ ПОБЕРЕЖЬЯ ЭСТОНИИ ОТ ХАРАКТЕРА И РЕЛЬЕФА КОРЕННЫХ ПОРОД
}

Влияние характера и рельефа поверхности коренных пород на морфологию абразионных берегов изучалось многими исследователями морских берегов (Зенкович, 1962; Леонтьев, 1961 и др.). Установленные ими общие закономерности можно полностью отнести и к современным абразионным морским берегам Эстонии. В настоящей статье сделана попытка дать обзор морфологии абразионных морских берегов Эстонии.

Соответствующие описания имеются в исследованиях по геологии и геоморфологии территории Эстонии начиная уже с середины XIX века. Так, Гельмерсен (Helmersen, 1856) сравнительно детально охарактеризовал современный клиф на п-ове Пакри, являющемся частью СевероЭстонского глинта. Однако лишь в 20-30-е годы XX века была предпринята попьтка обрисовать развитие абразионных берегов Эстонии на примере Северо-Эстонского глинта в зависимости от характера коренных пород, в которых эти берега выработаны. Наиболее значительными в этой области являются исследования Таммеканна (Tammekann, 1926, 1940), Эпика (Öpik, 1927) и Гирэ (Giere, 1932). Но и в других работах того времени (Vilbaste, 1939 и др.; Luha, 1927-1928 и др.; Orviku, 1935 и др.) содержатся важные данные об абразионных берегах Эстонии. В большей части этих работ рассматриваются абразионные берега Северо-Эстонского глинта и меньше внимания уделяется строению и развитию абразионных берегов других районов побережья Әстонии, несмотря на их сравнительно частую встречаемость среди древних и современных морских берегов. Объясняется это тем, что Северо-Эстонский глинт в современном виде является наиболее протяженным абразионным берегом, на отдельных участках которого клифы начали формироваться уже в позднеледниковое время. Теперь же, когда в результате проведенных в последние годы исследований прибавилось много нового материала по строению и динамике морских берегов Эстонии, имеется возможность охарактеризовать своеобразные черты строения абразиснных берегов, обусловленные коренными породами, опираясь уже на данные, относящиеся ко всему побережью Эстонии. Однако и в настоящее время во многих случаях необходимо пользоваться данными о Северо-Эстонском глинте. 
Следует напомнить, что крупные формы современного рельефа коренных пород (см. Orviku, Orviku jun., 1969) в соответствии с небольшим южғым и юго-восточным падением коренных пород выработались уже в дочетвертичное время как рельеф куэстообразных плато. С точки зрения абразионных берегов особый интерес представляет Северо-Эстонское плато. Северной границей его является куэстовый уступ, представленный в современном рельефе Северо-Эстонским глинтом.

Равнинный рельеф. названного плато выработан в ордовикских и силурийских известняках, в различной мере устойчивых к денудационным процессам. Поэтому уже в дочетвертичное время на плато в более устойчнвых породах выработались невысокие пластовые плато (возвышения) и пластовые уступы западного направления (вдоль простирания слоев). Қак краевая зона Северо-Әстонского плато, так и пластовые плато были уже в дочетвертичное время расчленены ложбинами стока и долинами в основном северо-западного и северного направления. Дочєтвертичный рельеф плато, за исключением куэстового уступа на северной окраине Северо-Эстонского плато, был в общем равнинный, с небольшими и относительно низкими пологими возвышениями.

Этот дочетвертичный рельеф коренных пород в плейстоцене в некоторой мере был преобразован деятельностью материковых льдов, местами друмлинизировался и стал еще более равнинным и расчлененным. Но общие черты дочетвертичного рельефа коренных пород все же сохранились до современного времени. На Северо-Эстонском плато, включая его пологие склоны, мощность покрова четвертичных отложений, представлегғых главным образом основной мореной, незначительна. Абразионные берега здесь раевивались большей частью в условиях поднятия земной коры и поэтому деятельность береговых процессов в определенной береговой зоне была кратковременной.

Эти общие черты геологического строения и развития Эстонского побережья, в частности в пределах Эстонского района побережья Балтийского моря (Orviku, Orviku jun., 1969), во многом предопределили морфологню и характер развития абразионных берегов начнная с позднеледникового до современного времени включительно.

Абразионные берега, как и вообще все берега Эстонии, являются отмелыми, независимо от того, относятся они к низменным или к обрывистым берегам. В Эстонии встречаются абразионные берега, выработанные как в четвертичных отложениях, в частности в моренах, так и в коренных породах. Последние, которые и рассматриваются ниже, представлены не только обрывистыми берегами, или клифами, но и низменными берегами.

Низменные абразионные берега в коренных породах описаны под названием скальных берегов (K. Orviku, Kaarel Orviku, 1961). Для скальных берегов характерна пологость подводного берегового склона и пляжа (надводной береговой нолосы), граница между которыми в поперечном разрезе берега не обнаруживает ясного изгиба, т. е. у этого берега отсутствует четкий абразионный обрыв. На скальных берегах абразии подвергается в основном подводный береговой склон, и выброс раздробленного материала с последнего на пляж происходит поперек береговой линии. Поэтому для скальных берегов характерны береговые валы донного питания, состоящие из слабоокатанного щебня известняковых пород. В современное время типичный скальный берег наблюдается в Эстонии на западном берегу п-ова Сырве у Лооде и на о-вах Вайка (рис. 1), расположенных к западу от о-ва Сааремаа (Орвнку К. мл., 1966).

На Северо-Эстонском плато, большие участки которого имеют равнинный рельеф коренных пород, скальные берега встречались во многих местах и в геологическом прошлом. Несомненно, что распространенные на побережье альвары образовались в свое время как скальные берега. Как известно, скальный берег на определенном участке побережья под влиянием поднятия земной коры может развиваться в течение длительного времени, при этом активная зона его беспрерывно перемещается в стсрону моря, отмершая же зона все расширяется и является той частью морской террасы, которую называют теперь альваром. Такое развитие скального берега можно хорошо проследить там, где наклон мористого склона рельефа коренных пород уже ясно выражен. Для примера можно указать на амфитеатр береговых валов Каугатума (Orviku, 1934), где 
ступенчатый мористый склон с относительной высотой до 12 м беспре. рывно развивался в течение многих тысячелетий как скальный берег, на отмирающие ступени которого нагромождались в порядке донного питания щебневые береговые валы.

В зависимости от характера коренных пород, подвергающихся действию береговых процессов, и от величины наклона мористого склона этих пород скальный берег может иметь несколько разновидностей. Скальный берег, формирующийся на слабонаклонной первичной поверхности коренных пород, можно назвать пологим скальным берегом. Последний, в свою очередь, подразделяется на ровный и неровный скальные берега. Ровный скальный берег образуется, в частности, там, где на пологом и ровном первичном склоне коренные породы, подвергающиеся абразии, имеют более или менее одинаковые слоистую текстуру и устойчивость к абразии и выветриванию. Для ровных пологих скальных берегов характерен пластовый бенч, не ограниченный со стороны суши абразионным обрывом. При развитии этих берегов в условиях постепенного отступания моря образовались и широкие полосы абразионных террас, в пределах которых обнажаются коренные породы и которые являются типичными альварами.

Пологий скальный берег, на котором абразии подвергаются пористые и трещиноватые биогермные доломиты, например рифовые образования яагарахуского горизонта (Aaloe, Miidel, 1967), и где поверхность коренных пород более или менее неровная и неспокойная, можно назвать неровным. И в этом случае на скальном берегу отсутствует типичный береговой обрыв. Такой характер имеют местами берега о-вов Вайка (рис. 1). Скальные берега, образовавшиеся в биогермных доломитах яагарахуского горизонта, встречаются и в пределах древних берегов, например в материковой части Западной Эстонии, в районе между Қайсма и Пярну-Яагупи (Aaloe, Miidel, 1967).

Другая разновидность скальных берегов формируется на мористых склонах первичного рельефа коренных пород, имеющих заметный наклон, например на более или менее пологих пластовых уступах. Если такие размываемые склоны древнего рельефа сложены более или менее однородными слоями известняковых пород, в них вырабатываются волнением ступени и в этом случае можно говорить о ступенчатом скальном береге. Протяженность и высота этих ступеней могут быть различными, продолжительность развития ступенчатого скального берега на определенном участке побережья также бывает разной в зависимости от местных условий. Например, в районе Каугатума ступени такого берега, выработанные в основном в тонкослоистых, более или менее однородных известняках каугатумаского горизонта, сравнительно большие, и развитие ступенчатого скального берега продолжалось здесь длительное время. В других местах, например на некоторых участках абразионного берега о-ва Осмуссаар (рис. 2) или на о-ве Вяйке-Пакри, ступени небольшие. Развитие таких ступенчатых скальных берегов было сравнительно кратковременным.

Ступенчатый скальный абразионный берег в коренных породах имеет бо́льшее значение в развитии берегов Эстонии, чем это до сих пор предполагалось. Такой берег описан Эпиком (Öpik, 1927) на о-вах Осмуссаар и Пакри как промежуточный между клифовым и низменным берегами и рассматривается им как разновидность отвесного клифа. Эпик считал этот берег характерным для осмуссаарского этапа развития Северо-Эстонского глинта. Ступенчатый скальный берег, как уже отмечалось, является разновидностью скального берега. Так как Эігк изучал только современные берега западной части Северо-Эстонского глинта, то 


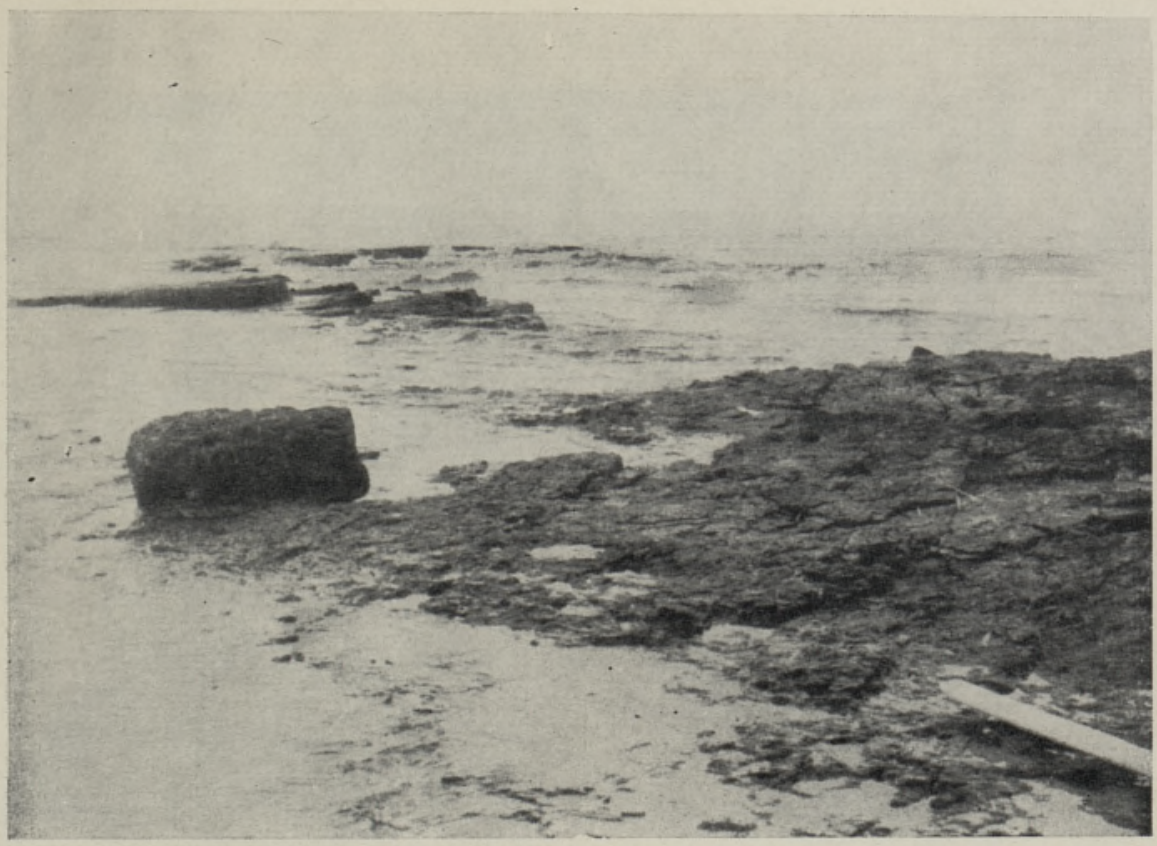

Рис. 1. Пологий неровный скальный берег на одном из островов Вайка (о-в Сааремаа), выработанный в рифовых доломитах яагарахуского горизонта (силур). Фото К. Орвику мл.

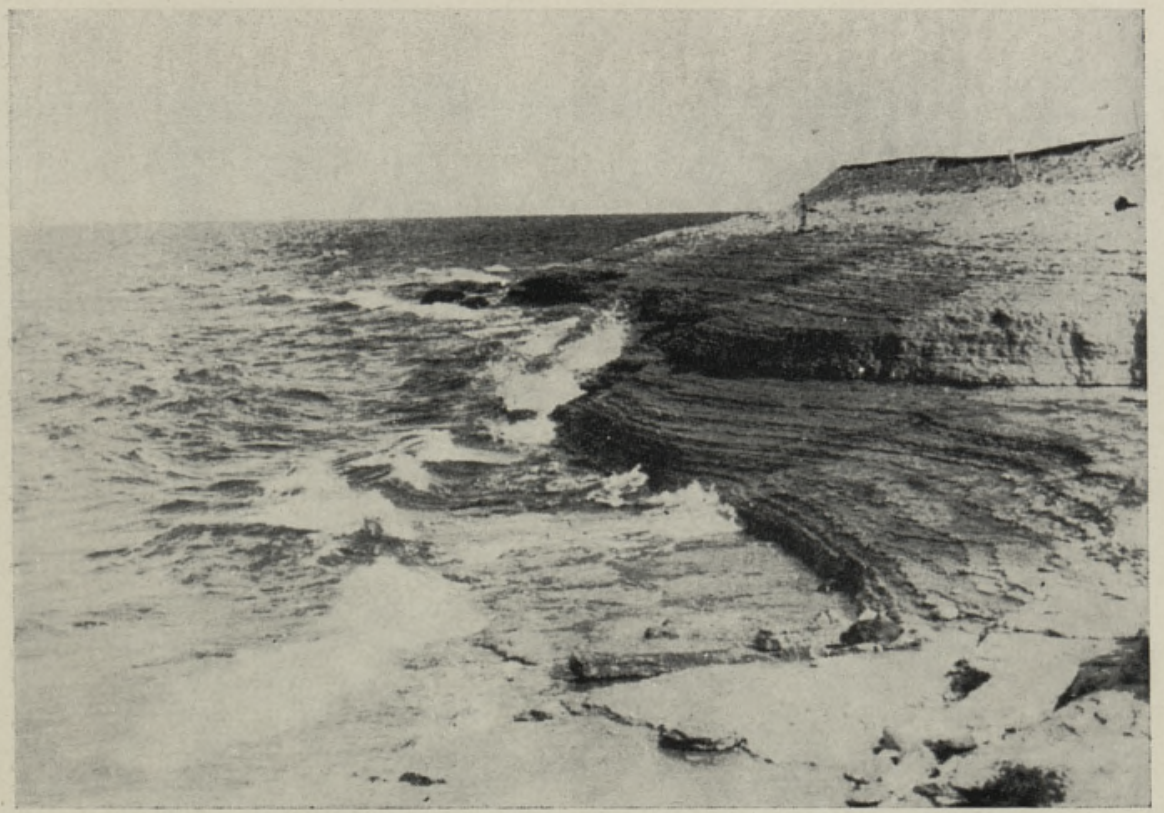

Рис. 2. Ступенчатый скальный берег на о-ве Осмуссаар, выработанный в слоистых известняках ласнамягиского горизонта (средний ордовик). Фото К. Орвику. 

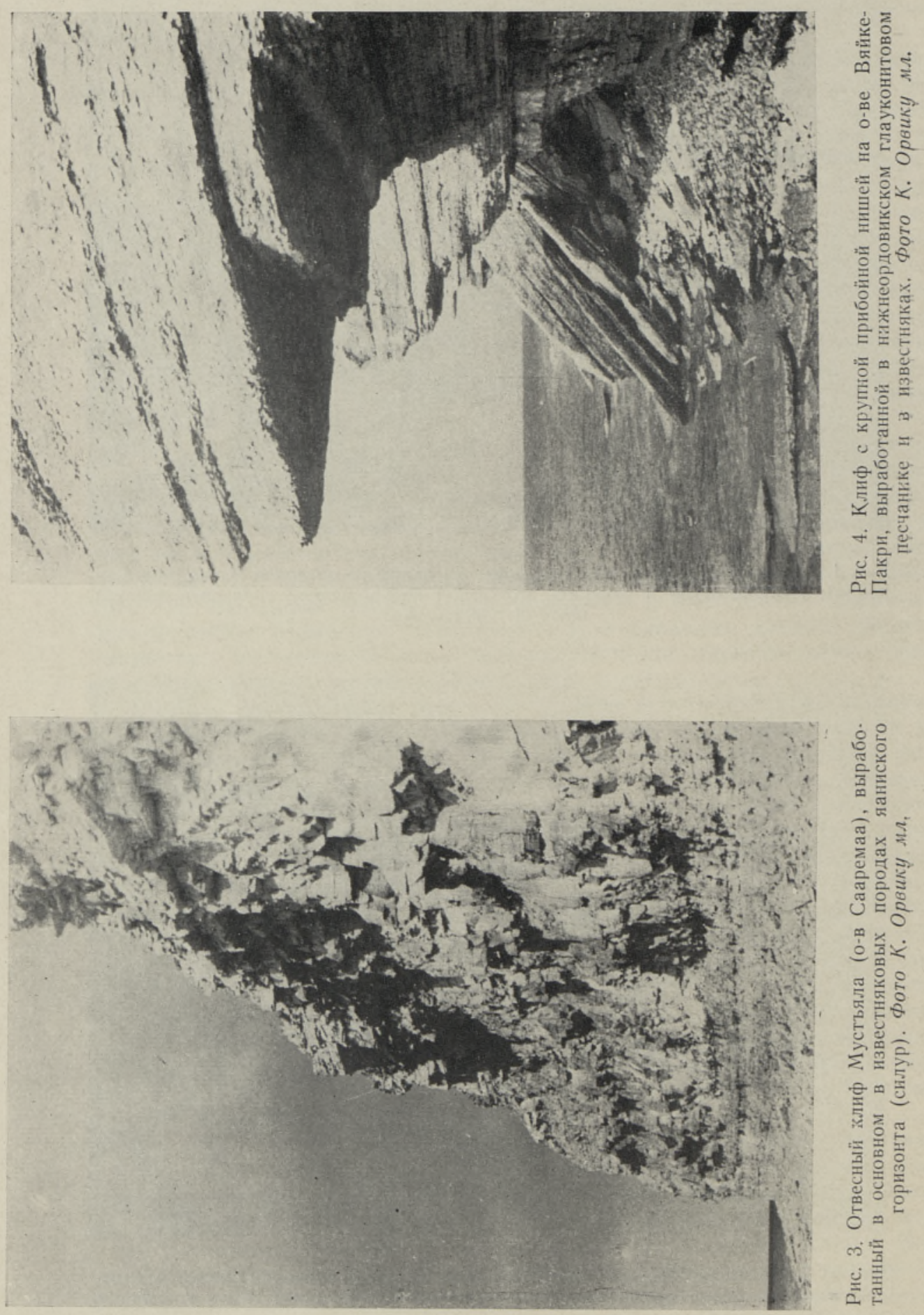

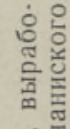
苋 $x$

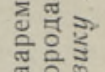

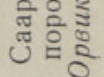

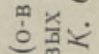
樀
뜬
造
玄兴
क्ष हैं
约
롤옹
$5 \approx$
ले
芒 

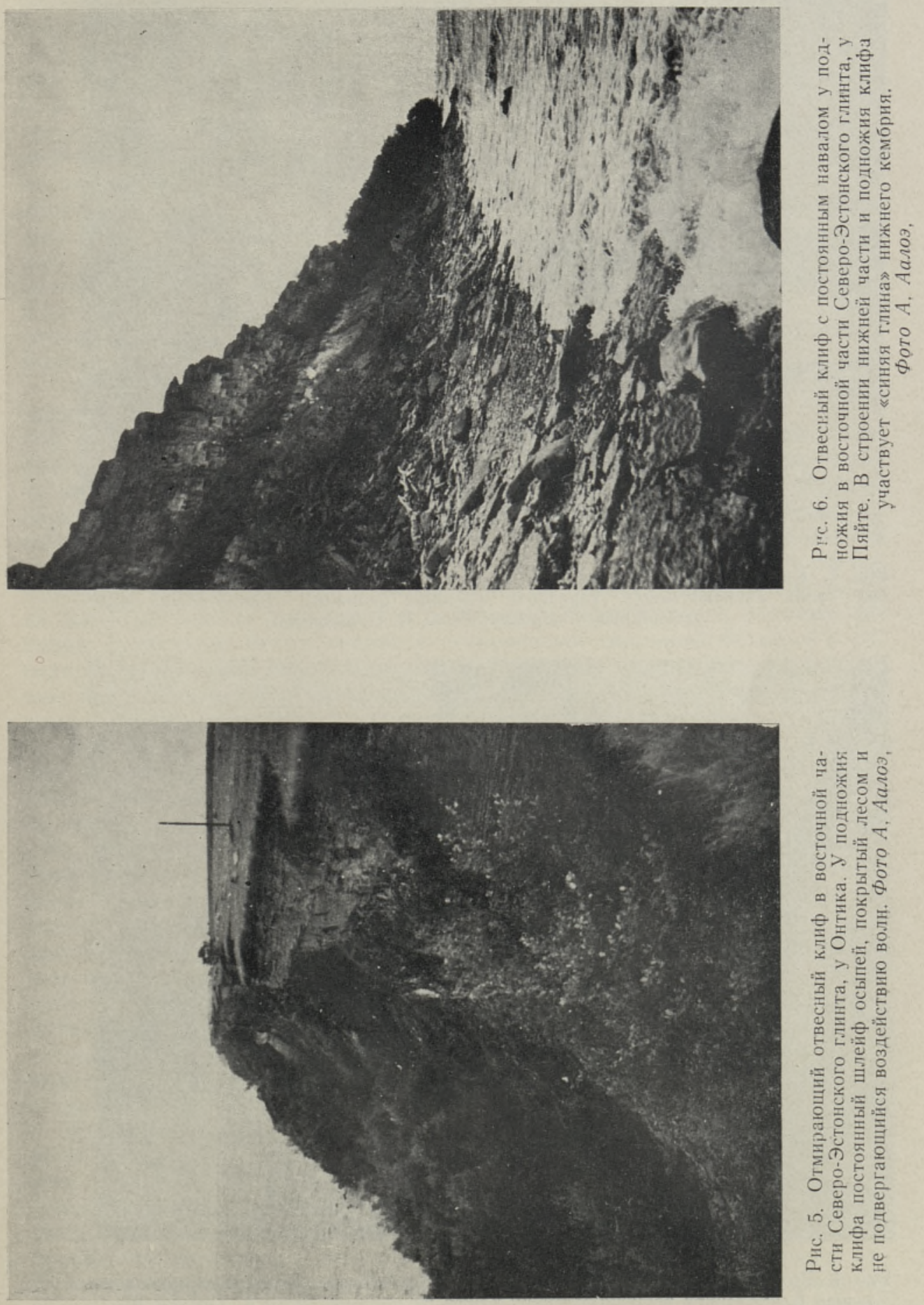


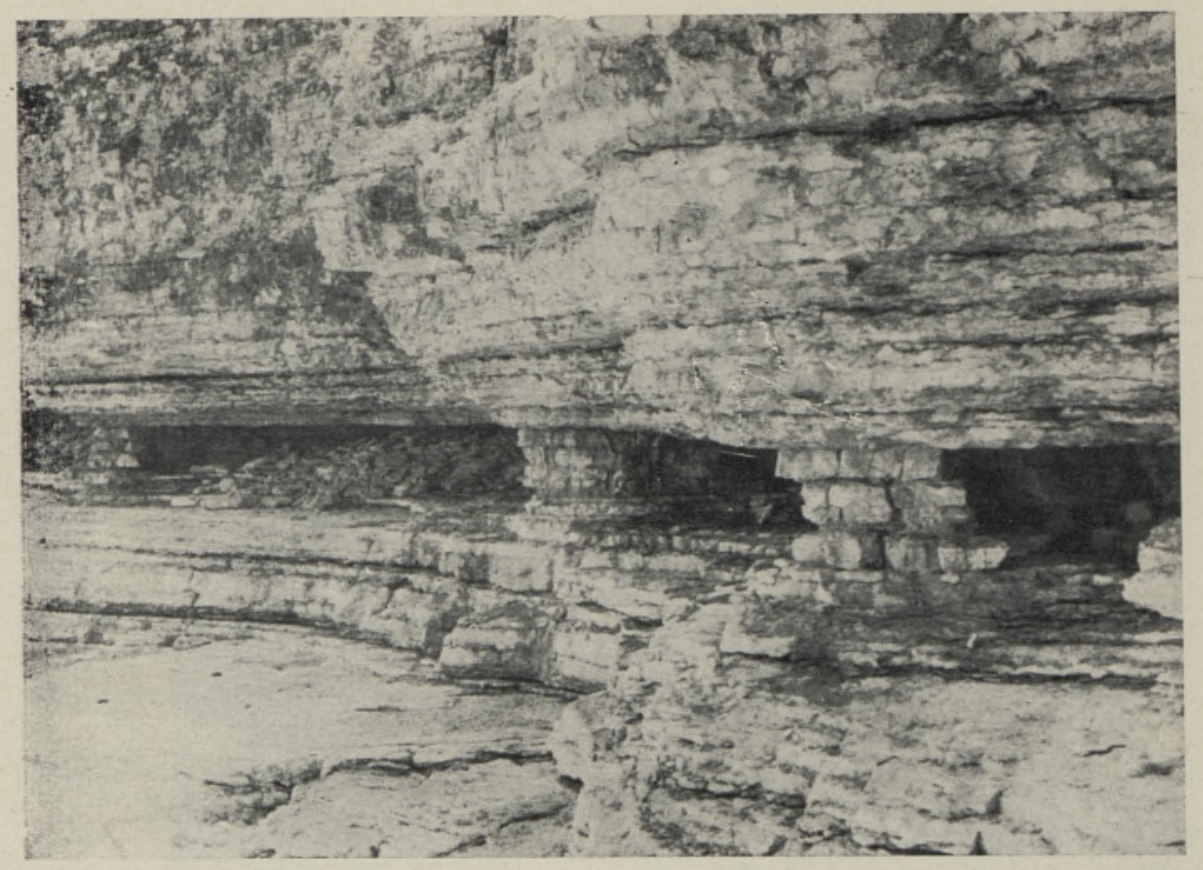

Рис. 7. Клиф с прибойными нишами на о-ве Осмуссаар, выработанными в нижних слоях ласнамягиского горизонта (средний ордовик), сравнительно мало устойчивых к абразин. Фото $K$. Орвику мл.

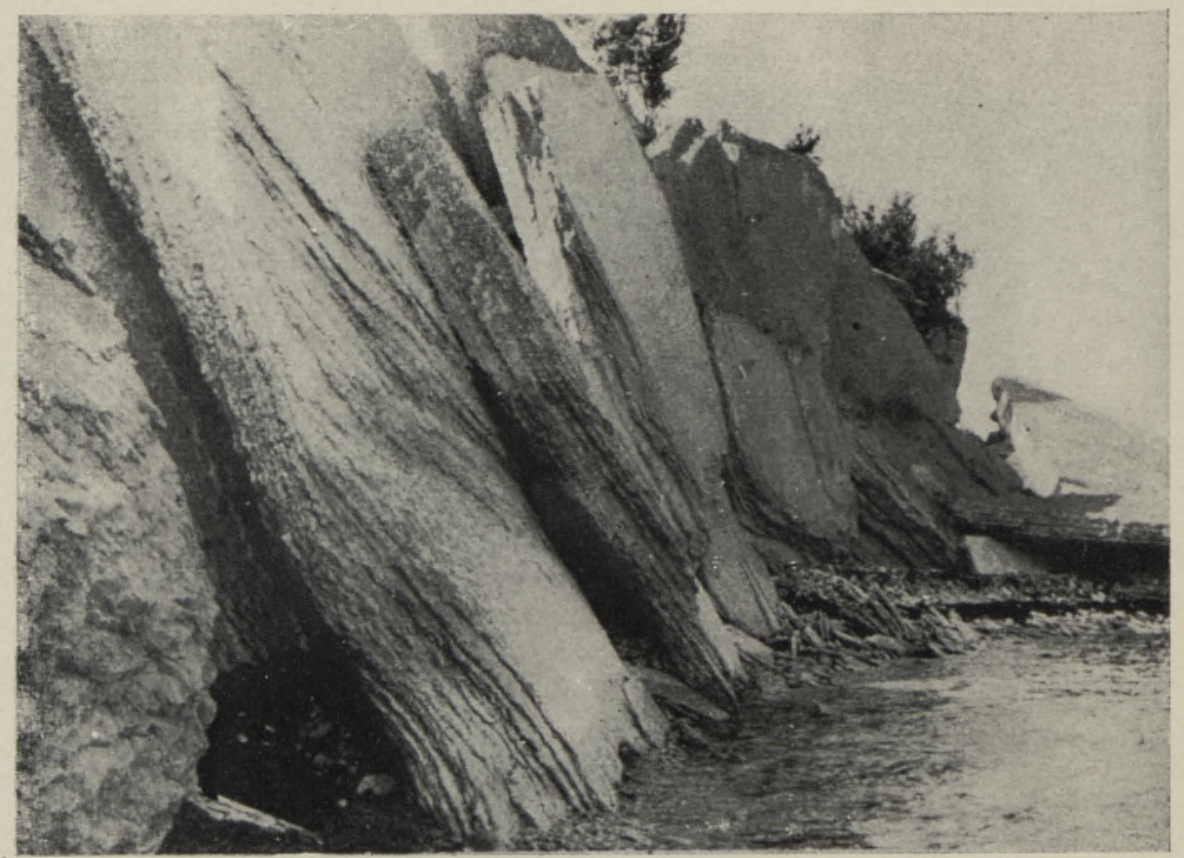

Рис. 8. Крупные известняковые глыбы в виде бронирующих щитов у подножия клифа Вяйке-Пакрн защищаютстенку клифа от абразин. Фото К. Орвику мл. 
понятно, что он считал ступенчатый скальный берег особенно характерным для острова Осмуссаар. В настоящее время такой берег установлен в типичном виде и в других местах Эстонского побережья, как среди современных, так и среди древних береговых образований.

Как уже отмечалось, ступенчатый скальный берег на определенных участках Эстонского побережья может развиваться длительное время. Скальный берег, в частности ступенчатый, обычно начинает формироваться на экспонированных действию волн б́ерегах островов и мысов, поднимающихся выше уровня моря. Вначале на таком берегу происходит нагромождение известнякового щебня в порядке донного питания. При продолжающемся поднятии земной коры острова и мысы, представляющие собой пологие возвышения рельефа коренных пород, в частности пластовые плато, постепенно увеличиваются в размерах. На более или менее пологих экспонированных склонах островов и мысов вырабатывается ступенчатый скальный берег, который на их боках, где уклон рельефа коренных пород уменьшается, может постепенно превратиться в ровный скальный берег.

На ступенчатых скальных берегах одновременно с разрушением подводного склона может происходить также абразия в надводной береговой полосе и наряду с донным питанием - транспорт каменного материала вдольбереговыми потоками с экспонированных участков берега на боковые берега островов и мысов, где он накапливается, образуя береговые валы, косы, и т. п. Так как ступенчатый скальный берег на экспонированных участках продолжает развиваться на все более низких уровнях пологого склона древнего рельефа, то наряду с этим и нагромождение каменного материала на боковых берегах также происходит на все более низких уровнях. Такое развитие берегов, когда районом питания длительное время является ступенчатый скальный берег, а в соседстве, на боковых берегах островов или мысов, накапливаются щебневые береговые валы и косы, которые тем моложе, чем ниже расположены, установлено во многих местах Эстонского побережья.

Там, где с продолжающимся поднятием берега воздействию береговых процессов подвергаются или более крутой склон рельефа коренных пород, или менее прочные породы, ступенчатый скальный берег может со временем смениться клифом, который вначале имеет небольшую высоту, а со временем значительно увеличивается в зависимости от величины поднятия берега и быстроты абразии пород. Соответствующие примеры имеются во многих местах Әстонского побережья. Например, на п-ове Мустъяла, где прослеживаются многочисленные цепи разновозрастных щебнево-галечных береговых валов, расположенных тем ниже, чем они моложе. Это свидетельствует о непрерывном поднятии полуострова, сначала в виде острова, на котором областью питания аккумулятивных береговых форм является ступенчатый скальный берег. Последний постепенно сменился клифом Мустъяла, длительное время служившим основным источником питания аккумулятивных берегов полуострова, развитие которых продолжается и в современное время.

Такой же характер развития абразионных берегов наблюдается и на островах Осмуссаар, Суур- и Вяйке-Пакри. На первом этапе развития этих островов здесь не было клифов, абразионные берега были скальными. При этом на островах накоплялся в значительном количестве щєбнево-галечный материал, о чем свидетельствуют береговые валы на бровке современных клифов этих островов, разрушающиеся по мере отступания клифов. Названные береговые валы, судя по их расположению относительно рельефа коренных пород, могли образоваться в свое время на этих островах лишь в условиях размыва скальных берегов. На тех же 
островах на бровке современных клифов местами сохранились остатки бывших ступенчатых скальных берегов.

Только при продолжающемся постепенном поднятии островов и мысов на их экспонированных действию волн берегах вместо скальных образовались обрывнстые берега - клифы, в частности там, где волновой деятельности подвергались менее устойчивые породы, чем вышележащие. Этот процесс продолжается и в современное время, соответственно тому, какие слои подвергаются абразии.

Наиболее подходящие условия для образования обрывистых берегов - клифов на Эстонском побережье существуют на более крутых северных и северо-западных склонах куэстовых плато и пластовых возвышений (последние нередко представлены друмлинизированными возвышениями юго-восточного направления), выработанных в головах слоев. Ссответственно крутизне и высоте размываемых склонов возвышений и продолжительности их размыва высота клифов колеблется от нескольких метров (в Охесааре) до нескольких десятков метров (в Пяйте). Длина активных клифов обычно небольшая - от нескольких сотен метров до нескольких километров.

В зависимости от устойчивости подвергающихся абразии пород клифы имеют различный морфологический облик. Наиболее детально изучены в этом отношении клифы Северо-Эстонского глинта Эпиком (Öpik, 1927), который описывает три разновидности клифов: отвесный, с прибойными нишами и с постоянным шлейфом осыпей. Он обратил также внимание на то, что выделенные им морфологические разновидности клифов, встречающиеся в современное время на Северо-Эстонсксм глинте одновременно в разных егс частях, закономерно сменяли друг друга при развитии глинта как абразионной формы рельефа соответственно тому, какие по устойчивости породы подвергались абразии. Исходя из этого, Эпик выделил следующие морфологические этапы развития Северо-Эстонского глинта: первый этап - осмуссаарский (ступенчатый скальный берег и отвесный клиф в известняках), за ним следуют рогэский (клиф с прибойными нишами) и пакриский (отвесный клиф, в нижней части которого размываются кембрийские песчаники) этапы; морфологическое развитие глинта как абразионной формы замыкается, по А. Эпику, этапом глинта.

Наиболее распространенной морфологической разновидностью клифа на Эстонском побережье является отвесный клиф, выработанный в ордовикских и силурийских известняках, т. е. в породах, выходы которых широко распространены в районе Эстонского побережья и которые при поднятии земной коры в первую очередь попадают в зону волновой деятельности, как это было отмечено выше.

Отвесный клиф образуется там, где абразии и выветриванию подвергаются породы с более или менее одинаковой устойчивостью к абразии и выветриванию. Об этом свидетельствует ряд современных клифов на о-ве Сааремаа, например клифы Охесааре, Мустъяла или Панга (рис. 3) и др. Типичным представителем морфологической разновидности отвесного клифа является клиф Мустъяла. Высота его отвесного обрыва, выработанного в силурийских известняковых породах, достигает 20 м. Нижнюю часть клифа образуют тонкослоистые мергели яаниского горизонта; на них залегают толстослоистые, сильно трещиноватые глинистые доломиты того же горизонта и в самой верхней части обрыва - пластинчатые доломиты с биогермными доломитами яагарахуского горизонта (Aaloe, Miidel, 1967). Более или менее одинаковая устойчивость этих пород к абразии (в нижней части клифа) и выветриванию (в верхней его части) обусловила длительное существование кли- 
фа в виде активного отвесного обрыва, подножие которого почти свободно ст навала каменного материала.

А. Эпик (Öрik, 1927) считает, что отвесный клиф типично представлен на о-ве Осмуссаар. Но там он все же менее типичен, чем в Мустъяла или в некоторых других местах о-ва Сааремаа. Как известно, одной из предпосылок образования отвесного клифа является одинаковая устойчивость к абразии и выветриванию слагающих клиф пород. Для примера можно указать на отвесный клиф Каутлику на о-ве Муху, выработанный в легко абрадируемых мергелях яаниского горизонта.

Конечно, отвесные клифы, например в Мустъяла, Охесааре, Каутлику и др., не имеют идеальной отвесной стенки. Обычно в стенке клифа выработаны небольшие выступы и ниши, обусловленные незначительными различиями в устойчивости слоев пород, участвующих в строенин клифа. Но при этом общий характер отвесности обрыва сохраняется. В пределах отвесных клифов могут местами и время от времени происходить значительные обвалы каменистого материала, вызванные трещиноватостью пород, слагающих клиф.

На Эстонском побережье многие отвесные клифы являются уже отмирающими или отмершими и находятся в пределах древних береговых образований. Отмиранию клифов способствует все продолжающееся поднятие земной коры, вследствие чего волны не в состоянии раздроблять и уносить весь каменный материал, накапливающийся у подножия клифа в виде осыпей и обвалов, которые и защищают клиф от абразии.

В районе Эстонского побережья встречаются отвесные клифы, выработанные не только в известняковых породах, но и в кембрийских песчаниках. Такой типичный отвесный клиф находится в настоящее время на мысе Пакри. Морфология и строение его описаны рядом исследователей (Helmersen, 1856; Öpik, 1927; Giere, 1932; Tammekann, 1940 и др.). У подножия этого клифа, сложенного ордовикскими известняками и кембрийскими песчаниками, постоянный шлейф осыпей и обвалов отсутствует. Аналогичные этому клифы прослеживаются еще в Тюрисалу и Раннамыйза, но уже не в таком типичном виде, как на мысе Пакри.

Клифы, сложенные в нижней части кембрийскими песчаниками и выше - комплексом нижне- и среднеордовикских слоев, более высокие - от 20 до $40 \mathrm{~m}$. Это способствует накоплению у подножия клифа значительного количества каменного материала, обрушивающегося с отвесной стенки клифа в результате выветривания. Если у подножия такого клифа все же не образуется постоянных навалов, не говоря уже о шлейфах осыпей, как это можно видеть на клифе Пакри, то это свидетельствует об интенсивной абразии клифа.

Еще бо́льшее значение приобретают обвалы и осыпи на более высо. ких (свыше 40 м) клифах в восточной части Северо-Эстонского глинта. Здесь у подножий отвесных клифов образовались уже постоянные шлейфы осыпей, защищающие отвесный обрыв от непосредственного волнового воздействия, сами же шлейфы подвергаются постоянной абразин, и каменный материал осыпей медленно сползает в сторону моря, чему спссобствуют еще более древние слои кембрия в нижней части клифа, в частности жсиняя глина». Последняя, несмотря на свой большой геологический возраст, обладает пластическими свойствами, и наклонная к морю промокшая поверхность ее способствует оползневым явлениям на шлейфе осыпей (Giere, 1932). Описанный клиф в типичном виде наблюдается в восточной части Северо-Эстонского глинта, у Пяйте, на протяжении нескольких километров (рис. 6), а также на небольшом участке близ Утрия.

5 ENSV TA Toimetised $\mathrm{K} * \mathrm{G}-269$ 
Среди активных клифов в районе Эстонского побережья, в частности на Северо-Эстонском глинте, можно найти ряд переходных форм между отвесным клифом с непостоянными осыпями у подножия (клиф Пакри) и клифом с постоянным шлейфом осыпей, размываемым волнами (клиф Пяйте), на что обратил внимание уже B. Гирэ (Giere, 1932).

Имеется также ряд переходных форм между активным отвесным клифом с постоянным, размываемым шлейфом осыпей у подножия клифа и отмирающим и отмершим клифом с характерным шлейфом осыпей, уже не размываемым волнами. На последнее указывает аккумулятивный берег мористее шлейфа осыпей. В то же время продолжается выветривание стенки клифа и осыпание и обрушивание каменного материала с нее на шлейф осыпей, который все расширяется, растет в высоту и уже бо́льшей частью зарос растительностью (лесом). Такой типичный отмирающий клиф прослеживается в восточной части Северо-Эстонского глинта, в окрестностях Онтика (рис. 5). Северо-Эстонский глинт в современное время только на небольших участках является активным клифом, в бо́льшей же своей части он уже отмер или отмирает. Отмирание глинта как абразионного берега на разных его участках происходило в голоцене в разное время в соответствии с местными геолого-геоморфологическими условиями.

Другая морфологическая разновидность клифов Эстонского побережья - клифы с прибойными нишами. Они вырабатываются там, где нижняя часть клифа, подвергающаяся волновой деятельности, состоит из менее устойчивых пород, чем верхняя часть, которая подвергается еще только воздействию выветривания. Типичный клиф с прибойными нишами на о-ве Вяйке-Пакри более детально описан Эпиком (Öpik, 1927).

Прибойные ниши в клифе на о-ве Вяйке-Пакри (высота до 12 м) размыты в основном в рыхлом глауконитовом песчанике нижнего ордовика (рис. 4), залегающем под нижне- и среднеордовикскими известняками. Из-за рыхлости глауконитового песчаника в последнем вырабатываются со временем настолько длинные и глубокие прибойные ниши, чтс залегающие выше и в общем устойчивые к абразии, но расчлененные системами вертикальных перекрещивающихся тектонических трещин известняки обрушиваются крупными глыбами к подножию клифа. Последние в виде наклоненных к морю каменных щитов препятствуют в течение длительного времени непосредственному размыву стенки клифа. Это можно наблюдать, например, в северо-западной части о-ва Вяйке-Пакри, где таких крупных глыб очень много (рис. 8).

Клифы с прибойными нишами встречаются в районе Эстонского побережья не только на Северо-Эстонском глинте, где абразии подвергается глауконитовый песчаник, но и повсюду, где в связи с поднятием берега в зону волновой деятельности попадают породы, менее устойчивые, чем вышележащие. Так, на северо-восточном берегу о-ва Осмуссаар можно наблюдать сравнительно большие прибойные ниши в нижней части клифа (рис. 7), которые образовались здесь в нижних слоях ласнамягиского горизонта, менее устойчивых против волнового действия, чем залегающие выше более толстослоистые и чистые известняки того же горизонта (Orviku, 1936). И в данном случае величина прибойных ниш обусловила обрушивание крупных глыб вышезалегающих пород к подножию клифа, т. е. здесь наблюдается та же картина, что и на острове Вяйке-Пакри.

Клифы с прибойными нишами встречаются также на выходах силурийских пород, там, где в зону волновой деятельности попадают менее 
устойчивые породы, покрытые более устойчивыми. Это можно наблю. дать на современном северном берегу о-ва Сааремаа, на клифе Пулли или Ойу. Нижнюю часть такого клифа образуют легко абрадируемые мергелистые слои яаниского горизонта, в которых выработаны волноприбойные ниши. В результате этого залегающие выше более компактные и устойчивые пластинчатые доломиты и биогермные доломиты яагарахуского горизонта обрушивались в виде крупных глыб к подножию клифа, длительное время защищающих стенку клифа от разрушительной деятельности волн, т. е. здесь наблюдается в основном то же явление, что и на о-ве Вяйке-Пакри.

В пределах древних, отмерших клифов также встречаются клифы с прибойными нишами. К числу их можно отнести, например, клиф Кирбла. Верхнюю часть его образуют биогермные доломиты яагарахуского горизонта, нижнюю - более легко размываемые пластинчатые доломиты того же горизонта, в которых водами Анцилового озера выработаны прибойные ниши. В общем такое же строение имеет самый крупный на о-ве Муху древний клиф Юугу, где прибойные ниши выработаны водами Лимниевого моря (Aaloe, Miidel, 1967).

Изложенное показывает, что в районе Эстонского побережья Балтийского моря во многих местах волновому действию подвергаются коренные породы, в частности разнородные известняковые слоистые породы ордовика и силура. Так как первичный рельеф коренных пород равнинный с небольшими возвышениями и в пределах рассматриваемого района с позднеледникового до современного времени происходит медленное суммарное поднятие земной коры, то на поднимающихся абразионных берегах в коренных породах в первую очередь образуются низменные скальные берега. Соответственно наклону мористого склона рельефа коренных пород, характеру залегания и степени устойчивости коренных пород к абразии и выветриванию низменный скальный берег морфологически может быть представлен пологим ровным или пологим неровным, или ступенчатым скальным берегом. Предпосылки для образования клифов создаются там, где мористый склон рельефа коренных пород имеет больший наклон. Морфологическое строение клифов во многом зависит от залегания и степени устойчивости к абразии и выветриванию коренных пород. В породах, более или менее одинаково устойчивых к абразии и выветриванию, вырабатывается отвесный клиф. $\mathrm{y}$ подножий большинства активных клифов постоянные шлейфы осыпей отсутствуют. Лишь там, где нижняя часть клифа образована кембрийскими глинами, встречается активный отвесный клиф с постоянным шлейфом осыпей, размываемым волнами. Там, где нижняя часть клифа сложена малоустойчивыми породами, на которых залегают более устойчивые породы, в первых вырабатываются крупные прибойные ниши.

Охарактеризованные выше абразионные берега в коренных породах встречаются на территории всего района Эстонского побережья. Возникновение и отмирание тех или других разновидностей скальных берегов и клифов на этой территории происходило в разное время, в соответствии с местными геолого-геоморфологическими условиями. 


\section{Л ИТ Е Р А Т Р А}

З ен кович В. П. 1962. Основы учения о развитии морских берегов. М.

Л е онтьев О. Қ. 1961. Основы геоморфологии морских берегов. М.

О р в и ку К. К. (мл.) 1966. Этапы развнтия небольших прибрежных островов в условиях подкятия земной коры на Северо-Западе Эстонии. В сб.: Развитие морских берегов в условиях колебательных движений земной коры. Ин-т геол. АН ЭССР. Таллин.

A a 1 o e A., Mi i d e 1 A. 1967. Eesti pangad ja joad. Tallinn.

Gi ere W., 1932. Morphologie der estländischen Nordküste. Veröffentlichungen des Geographischen Instituts der Albertus-Universität zu Königsberg i. Pr., N. F. Reihe Geographie, Nr. 6.

Helmersen G. 1856. Ueber das langsame Emporsteigen der Ufer des Baltischen Meeres und die Wirkung der Wellen und des Eises auf dieselben. Bull. de la classe physico-mathématique Acad. Sci. St.-Pétersb., ser. I, 14, No. 13-14.

L u h a A. 1927-1928. Pilte Muhu ja Saaremaa pankadest. Rahvaülikool, 1927, nr. 2, 1928, nr. 3.

O rviku K. 1934. Anseküla pinnaehitus. Koguteos «Eesti», VI. «Saaremaa». Tartu.

O rviku K. 1936. Ehituslubjakivi murenemisvastupidavusest. Eesti Loodus, nr. 1.

O rviku K., Orviku Kaarel. 1961. Jooni Eesti tänapäevase ranniku geoloogiast. ENSV TA Geoloogia Instituudi uurimused, VII.

Orviku K., Orviku K. jun. 1969. Ober die Beständigkeit der Entwicklung der Küsten im Estländischen Küstengebiet in der Spätglazial, im Holozän und in der Gegenwart. ENSV TA Toimet. Keem., Geol., 18, nr. 2.

T a mmekann A. 1926. Die Oberflächengestaltung des nordestländischen Küstentafellandes. Acta Univ. Tartu, A. 9, nr. 7.

T a m me k a n n A. 1940. The Baltic Glint. Morphography of the Glint. A geomorphological Study. Eesti Loodusteaduste Arhiiv, Seer. I, 11, vihik 3/4.

V il b a s te G. 1939. Pōhja-Eesti rannamoodustised. Tallinn.

Ö pik A. 1927. Die Inseln Odensholm und Rogö. Ein Beitrag zur Geologie von NWEstland. Acta Univ. Tartu. A. 12, nr. 2.

$\begin{array}{cc}\text { Институт геологии } & \text { Поступнла в редакцию } \\ \text { Академии наук Эстонской ССР } & 28 / \mathrm{XII} 1968\end{array}$

\section{K. ORVIKU, K. ORVIKU jun.}

\section{MURRUTUSRANNA MORFOLOOGIA SOLTUVUS PEALISKORRA KIVIMITEST JA RELJEEFIST EESTI KERKIVATEL RANDADEL}

Eesti nii nüüdisaegsetel kui ka vanadel randadel leidub pealiskorra kivimeisse kujınenud murrutusrandasid. Nende morfoloogia sōltub suurel määral kivimite vastupidavusest murrutusele ja vanast reljeefist. Vastavalt sellele on pealiskorras kujunenud murrutusrannad artiklis jaotatud reaks morfoloogilisteks erimiteks ning antud nende iseloomustus.

Lauskranna piirides esinev kaljurand on jaotatud laugeks kaljurannaks, mis esineb tüüpilisena Sōrve poolsaare läänerannal Loode juures ja kohati Vaika saartel (joon. 1), ja astmeliseks kaljurannaks, mis esineb tüüpilisena kohati Osmussaarel (joon. 2). Lauge kaljurand esineb kas tasasena või ebatasasena. Vanad kaljurannad esinevad loopealsetena.

Järsakrand esineb pealiskorra kivimeis klifina. Ohesuguse murrutusvastupidavusega pealiskorra kivimeis kujuneb järsakrand välja järsuseinalise klifina, mis tüüpiliselt esineb Mustjala pangal (joon. 3). Järsuseinalise klifiga on tegemist ka seal, kus klifi jalamil tekib pidev ja püsiv murrutusele alluv rusukaldevööde, nagu see tüüpilisena esineb PōhjaEesti panga idaosas Päite klifil (joon. 6). Seal aga, kus klifi jalamil esinev pidev rusıkaldevööde murrutamisele enam ei allu, näiteks Pöhja-Eesti paekalda! Ontika ümbruses (joon. 5), ei ole enam tegemist aktiivse klifiga, vaid juba hääbuva vōi hääbunuga.

Kus klifi alumise osa moodustavad kivimid on vähema murrutusvastupidavusega kui klifi ülemist osa moodustavad, kujuneb murrutuskulbastega kliff (joon. 4), nagu see tüüpilisena esineb kohati Väike-Pakri saarel. Suurte murrutuskulbaste lagi variseb kohati klifi jalamile suurte pangastena, kaitstes pikemaks ajaks klifi seinu murrutuse eest (joon. 8). 
K. ORVIKU, K. ORVIKU jun.

\section{DIE ABHÄNGIGKEIT DER MORPHOLOGISCHEN GESTALT DER ABRASIONSKUSTE VOM CHARAKTER DER UNTERGRUNDGESTEINE UND VOM RELIEF DES UNTERGRUNDES AUF DEN AUFTAUCHKUSTEN ESTLANDS}

Unter gegenwärtigen und alten Küsten Estlands finden sich Abrasionsküsten, in den Untergrundgesteinen ausgearbeitet. Der morphologische Charakter dieser Küsten hängt in hohem Maße von der Widerstandsfähigkeit der Untergrundgesteine und von dem alten Relief des Untergrundes ab. Dementsprechend werden die Abrasionsküsten Estlands im Artikel nach ihrer morphologischen Gestalt in eine Reihe Typen eingeteilt und die letzten charakterisiert.

Die Flachküste in den Kalksteinen wird als Felsküste beschrieben. Letztere zerfällt in die flache Felsküste, typisch bei Loode, auf der Westküste der Halbinsel Sõrve und auf den kleinen Inseln Vaika zu finden (Abb. 1), und die stufige Felsküste, typisch für einige Stellen der Insel Osmussaar (Abb. 2). Die flache Felsküste wird ferner in die ebene flache Felsküste und die unebene flache Felsküste eingeteilt. Die alten Felsküsten sind als Alvargebiete vertreten.

Die steilen Abrasionsküsten in den Gesteinen des Untergrundes werden als Kliffe beschrieben. Wo die Untergrundgesteine von gleichartiger Abrasionsfestigkeit sind, wird der steilwandige Kliff ausgebildet, so z. B. typisch bei Mustjala (Abb. 3). Ist am FuBe des Kliffs eine beständige Kliffhalde entstanden, welche noch vom Wellengange abradiert wird, so kann man von einem Kliff mit beständiger abradierbarer Kliffhalde reden. So ein Kliff ist bei Päite, im östlichen Teil des Nord-Estländischen Glintes, typisch ausgebildet (Abb. 6). Wo aber die Kliffhalde nicht mehr vom Wellengange abradiert wird, zum Beispiel im östlichen Teile des Nord-Estländischen Glintes in der Umgegend von Ontika (Abb. 5), da hat man es nicht mehr mit einem aktiven, sondern mit einem inaktiven Kliff zu tun.

Wo aber der untere Teil des Kliffs aus weniger abrasionsfesten Gesteinen besteht als der obere Teil, da bilden sich Brandungshöhlen. Letzteres ist für einige Küstenstrecken der Insel Väike-Pakri bezeichnend (Abb. 4). Die großen Brandungshöhlen verursachen das Abstürzen großer Blöcke zum Fuße der Kliffe, wodurch die Abrasion der Steilwand für eine längere Zeit unterbrochen wird (Abb. 8). 